\title{
London Eyes: William Dean Howells and the Shift to Instant Photography
}

\author{
OWEN CLAYTON
}

Mr. Howells's pictures are not mere stiff, hard, accurate photographs; they are photographs with feeling in them.

—Mark Twain, "William Dean Howells" (1906)

As in stereoscopic or kinetoscopic pictures seen outside the instrument, the third dimension, the movement, the vital element, are not there. We get a beautiful picture of an express train supposed to be moving, but where in the picture, as I have heard a friend say, is the energy or the fifty miles an hour?

-William James, The Varieties of Religious Experience (1902)

$\tau$

OWARD the end of the nineteenth century, one of William Dean How-

ells's avid readers, meeting him in the flesh for the first time,

Nineteenth-Century Literature, Vol. 65, No. 3, pp. 374-394. ISSN: o891-9356, online ISSN: $1067-$ 8352. (C) 2010 by The Regents of the University of California. All rights reserved. Please direct all requests for permission to photocopy or reproduce article content through the University of California Press's Rights and Permissions website, at http://www.ucpress.edu/journals/ rights.htm. 
expressed surprise that the famed author was still alive. ${ }^{1}$ Although he had not actually departed from the world, by this time the venerable "Dean" appeared to be at a low creative ebb. While writers such as Frank Norris were taking the novel in directions about which Howells was, at the least, ambivalent, he sometimes felt that his own best work was behind him. Nevertheless, in 1903, he completed The Son of Royal Langbrith, generally considered the finest of his later books, and then, in the following year, he left for England to collect material for a book about his country's Puritan ancestry. ${ }^{2}$ A few weeks after arriving at Plymouth in Devon, though suffering from fatigue and an unfortunate bout of nervous dyspepsia, he wrote excitedly to his wife, Elinor: "What a book I could make about England!" ${ }^{3}$ His excitement stemmed from the fact that he was now contemplating an English travel narrative, following in the tradition of Ralph Waldo Emerson's English Traits $\left(185^{6}\right)$. In order to present the most modern view of contemporary England, Howells decided to make use of an extended metaphor that would associate his perspective with that of the recently invented and immensely popular Kodak camera. This conceit was to provide the energy for a new type of empirical reportage, neither romance nor traditional realism, which might enable him to move beyond established epistemological foundations. ${ }^{4}$ Not surprisingly,

${ }^{1}$ See Daniel H. Borus, Writing Realism: Howells, James, and Norris in the Mass Market (Chapel Hill: Univ. of North Carolina Press, 1989), p. 107. I wish to thank my supervisors, Bridget Bennett and Katherine Mullin, for their wonderful help and support. My thanks also go to the William Dean Howells Society for their enthusiastic encouragement of my work. The research undertaken at the Houghton Library was made possible by a Brotherton Library Scholarship from the University of Leeds. Finally, thanks to my wife, Jen, who read through more drafts of this article than either of us cares to remember.

${ }^{2}$ In a letter to Aurelia Howells, dated 21 February 1904, Howells announces that he will travel to England on the Molke on 3 March. See William Dean Howells, letter to Aurelia Howells, Houghton Library Collection, Harvard Univ., bMS Am I 784.I3 (IO). By permission of the Houghton Library, Harvard University.

${ }^{3}$ William Dean Howells, letter to Elinor Howells, 24 April 1904, in Life in Letters of William Dean Howells, ed. Mildred Howells, 2 vols. (New York: Doubleday, Doran, and Co., 1928), II, 198; emphasis in original.

${ }^{4}$ Howells was a realist inasmuch as he believed in literature's ability to create a recognizable connection with "actual life." Because it is not self-evident, any writer's decision to employ this link is a political act. 
twentieth- and twenty-first-century criticism has overlooked this endeavor, which Howells buried away in the now-neglected travelogue London Films (1905). In this essay I demonstrate the way in which Howells uses the figure of instant photography to question positivistic observational assumptions, as he attempts to unite subjective and objective forms of knowledge in response to the theories of his friend and contemporary, William James. Finally, I argue that the issue of poverty ultimately led Howells to turn his back on this project.

From the inception of photography in the 1840 , many writers used visual recording technologies as straightforward points of comparison for literature that strove to document the "real" accurately. ${ }^{5}$ Numerous critics have linked this medium with nineteenth-century realists, yet there is a paucity of such analysis in relation to the work of Howells. ${ }^{6}$ Such a gap is surprising, given that he frequently linked the two arts. For example, in his well-known comparison of real and "ideal" grasshoppers, he called the method required to study the "natural" grasshoppers "photographic." In doing so, he explicitly paralleled his mode of writing with the assumed qualities of photography: objectivity, attention to detail and the everyday. Throughout his career, Howells wrote about different photographies as if they were symptomatic of literature, with attentiveness to the limitations and peculiarities of particular methods. Changes in technology influenced his tone and style, as well as the various ways in which he set himself up as the champion of realism. He was aware that if a work were "photographic" only in the sense of accumulating particulars, then it would lack sufficient pathos either to affect or maintain a readership. The challenge for Howells and other realists was how to approximate the best

\footnotetext{
${ }^{5}$ There was another tradition of comparison within nineteenth-century realism, one that took a greater account of photography's malleability, reflecting a constructed rather than a recorded reality. See Daniel A. Novak, Realism, Photography, and NineteenthCentury Fiction (Cambridge: Cambridge Univ. Press, 2008).

${ }^{6}$ For example, see the discussion of Henry James in Jennifer Green-Lewis, Framing the Victorians: Photography and the Culture of Realism (Ithaca: Cornell Univ. Press, 1996).

${ }^{7}$ William Dean Howells, Criticism and Fiction (1891), in his Selected Literary Criticism, Volume II: I886-I897, ed. Donald Pizer and Christoph K. Lohmann, et al., vol. 21 of A Selected Edition of W. D. Howells (Bloomington and Indianapolis: Indiana Univ. Press, 1993), p. 301.
} 
qualities of photography without losing "feeling," that most "vital element" of writing. ${ }^{8}$

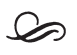

In the January 1888 edition of his "Editor Study" column, Howells reviewed Jeannette H. Walworth's Southern Silhouettes (1887), a work that opens with its author's claim that her character portrayals "are not the work of imagination, but are accurate out-lines of actual entities." ${ }^{9}$ In his review, Howells disputed this assertion by using a figure of photographic manipulation: "one feels that the negatives have been touched, and that is always to be regretted." 10 He implies that Walworth creates characters who behave in a way that is convenient for her sense of propriety, rather than creating them to behave how people actually act. His metaphor splits the medium of photography into two, commending and condemning different aspects of photographic writing, admiring close attention to detail but denigrating the preparation-development stage. He connects this latter stage with "romantic" authorial manipulation, but he retains exposure as a "realist" moment, a move that enables him to claim: "So skilful a hand as Miss Walworth's should be taught when to hold itself" (Editor's Study, p. 117 ). Behind this somewhat patronizing injunction is the belief that, if she stuck to recording rather than inventing details, Walworth would come nearer to her goal of representing things as they are. It is clear that, in this conception of photography as a literary metaphor, Howells regards realism as autotelic: an author needs to learn not only how to write, but also how to hold back the temptation to overwrite.

\footnotetext{
${ }^{8}$ See Mark Twain, "William Dean Howells," Harper's Monthly Magazine, 113 (1906), 223; and William James, The Varieties of Religious Experience: A Study in Human Nature: Being the Gifford Lectures on Natural Religion Delivered at Edinburgh in I9OI-I9O2 (New York: Longmans, Green, and Co., 1902), p. $5^{\mathrm{O} 2}$.

${ }^{9}$ Walworth, "Introductory," in her Southern Silhouettes (New York: Henry Holt and Co., 1887), p. iii.

${ }^{10}$ William Dean Howells, "Editor's Study" (January 1888), rpt. in his Editor's Study, ed. James W. Simpson (Troy, N.Y.: Whitson Publishing Co., 1983), p. 117.
} 
In a November 1888 "Editor's Study" column, Howells conflates the process of literary creation with the newly invented Kodak, pondering the possibilities of a hypothetical realist carrying a "snap-camera" to record individual impressions. This idea suggests Howells's wish to record life "as it comes," by dispensing with the manipulative development process. ${ }^{11}$ He would hold back this desire until the twentieth century, finally realizing it through the writing of London Films. By then, Kodak had released the "Brownie" model, which was the first camera to achieve mass-market success in the modern sense, as well as the first Kodak that Howells himself owned. It does not take an enormous leap to imagine that a shift in a technology that he had previously identified with realism would provide a useful starting point from which to investigate the limits of that mode. His decision to test those limits within the genre of travel writing was commonsensical, given that the EastmanKodak company had aggressively marketed their products at prospective tourists. In London Films Howells makes it clear that the popular expansion of image-making represented a move toward greater individualism and democracy, a change that aligned photography even more closely with his particular strand of literary realism.

London Films operates under the premise that Howellsas-narrator "carries a mental kodak with him" in his journeys around London, with the author stating that his intention is to record what he sees on his "mental films" and then to relay these sights back to the reader. ${ }^{12}$ He claims that it is necessary to "be aware of the uncertain value of the different exposures" (London Films, p. 1). This phrase means the taking of one picture after another, and the inevitable discrepancy in quality that will occur. It also implies, however, the various types of exposure

${ }^{11}$ William Dean Howells, "Editor's Study" (November 1888), in Editor's Study, p. 165 . The fact that the Kodak did not require specialist knowledge related to photographic development was, of course, its main selling point, as epitomized in the slogan "You press the button, we do the rest."

12 William Dean Howells, London Films (1905), in "London Films" and "Certain Delightful English Towns" (New York: Harper and Brothers, 1911), p. 2. All subsequent references for London Films are from this edition and are given parenthetically within the body of this essay. 
made possible by different technologies. The self-conscious use of the Kodak metaphor, while retaining the medium's culturally defined epistemological claims, provides two elements that are typically associated with non-realist structures of thought: physicality and instaniety. ${ }^{13}$

The first advance, physicality, concerns "vernacular photography." By the early twentieth century, commercial cameras had transformed thousands of people from being sitters for photographs to being producers of them. As a result, the recording of images was no longer the domain of private studios, but of ordinary men and women on the street. Most of those who used the Brownie did so in a free-form way; that is, without the use of a tripod or other equipment to level the camera. Consequently, the physical position and perspective of the human operator became essential to the shot: she or he needed to negotiate height, angle, and movement at the point of exposure. This represented a new aesthetic because it arranged not only the bodies of the observed, as older methodologies did, but also the body of the observer. The Kodak's second advance, instaniety, meant that people could use the new cameras "spontaneously," without spending time composing their shot. The final images were often fragmented and impressionistic, a poor fit with earlier uses of the medium as evidence. Such amateur photographs are concomitant with Howells's desire to create art from life "as it comes."

The narrator of London Films refers to himself as "the present kodak" (London Films, p. 18), implying an embodiment, an acknowledgment of his being (in both senses of that word), within his current surroundings. He contrasts the typical "mind's eye" with his own "body's eye," a form of perception that highlights and brings together the location and internal sensations of the human frame (p. 148). This leads him not only to describe London's busy thoroughfares in close detail,

\footnotetext{
${ }^{13}$ Both elements are traditionally "non-realist" because they emphasize subjective experience over objective reality. See Georg Lukács's classic discussion of James Joyce in his "Realism in the Balance" (1938), trans. Rodney Livingstone, in Ernst Bloch, Georg Lukács, et al., Aesthetics and Politics, ed. Ronald Taylor (London and New York: Verso, 1977), pp. 28-59.
} 
but also to include the emotions induced by being within such tightly congested crowds:

The swelling and towering omnibuses, the huge trucks and wagons and carriages, the impetuous hansoms and the more sobered four-wheelers, the pony-carts, donkey-carts, handcarts, and bicycles which fearlessly find their way amid the turmoil, with foot-passengers winding in and out, and covering the sidewalks with their multitude, give the effect of a single monstrous organism, which writhes swiftly along the channel where it had run in the figure of a flood till you were tired of that metaphor. (pp. 12-13)

This London is rhythmic, as if it were a tidal force. The passage echoes the contemporary sociological interest in the issue of crowd flow, while the representation of the citizenry as a sea monster plays on Thomas Hobbes's famous image of the Leviathan. ${ }^{14}$ In this context, the "flood" might hint that the scene is an urban dystopia in which individuals submit to a larger, tyrannical body. The description, however, satirizes this use of figurative language through its delayed introduction of weariness, which creates suspense, drawing the reader in by using the second person, and then, with characteristic humor, undermines it. The text maintains both a subjective and an objective impression: the crowd is a monster, but only as part of textual play. Despite the narrator being apparently "tired" of this metaphor, Howells continues to utilize it, suggesting that one reason for using that word was to introduce the concept of physicality. As with Alfred Stieglitz's famous photograph of New York, Winter, Fifth Avenue (1892), this textual image connotes the sensation of being present in the scene. That the omnibuses are "towering" intimates the body of the person over

${ }^{14}$ In 1895 Gustave Le Bon claimed that society had entered "the era of crowds," and in 1903 Georg Simmel noted the defensive precautions that the mind takes in reaction to "the intensification of emotional life due to the swift and continuous shift of external and internal stimuli" caused by living within a metropolis. See Gustave Le Bon, The Crowd: A Study of the Popular Mind (New York: Viking Press, 196o), p. 14 (originally published in French in 1895 and translated into English in 1896); and Georg Simmel, "The Metropolis and Mental Life" (1903), trans. Edward A. Shils, rpt. in Simmel, On Individuality and Social Forms: Selected Writings, ed. Donald N. Levine (Chicago: Univ. of Chicago Press, 1971), p. 325 . 
whom they tower, as well as the ominous feelings that such a looming presence implies. The alliterative "fearlessly find . . . foot-passengers" connotes the noise of feet as pedestrians shuffle up against each other, while the adjectives give a sense of mass and movement, and the long sentence and hurried syntax re-create the oncoming rush of traffic and people. These technical attempts to communicate a phenomenology of the crowd parallel, among others, Virginia Woolf's depiction of similar scenes in Mrs. Dalloway (1925). ${ }^{15}$ London Films does not create its reports via unmediated observation but rather through "effect," in terms of what being inside such an assembly feels like.

For Howells the omnibus's peculiar mixture of the modern and the archaic makes it metonymic of London: "If ever London has her epic poet, I think he will sing the omnibus" (London Films, p. 49) ${ }^{16}$ Since the omnibus was a vehicle that was open to use by most classes, it is unsurprising that when the narrator boards one, the "monstrous" metaphor returns: "You are now a molecule of that vast organism, as you sit under your umbrella on your omnibus-top, with the public waterproof apron across your knees, and feel in supreme degree the insensate exultation of being part of the largest thing of its kind in the world, or perhaps the universe" (London Films, p. 13). The terms "molecule" and "organism" shift from the earlier fantastical mode of description to the discourse of science. Yet the narrator is within this scene, rather than, like a biologist performing an experiment, studying it from the outside. The umbrella and waterproof apron signify an enmeshing of the narrator with the content: if this is an experiment, then it is one in which he includes both himself and the reader. The repetition of "you" and "your" implies the isolation and insignificance of each individual, while "insensate exultation" gives a paradoxical impression of being alone in a group of people,

15 "In people's eyes, in the swing, tramp, and trudge; in the bellow and the uproar; the carriages, motor cars, omnibuses, vans, sandwich men shuffling and swinging; brass bands; barrel organs"; "The British middle classes sitting sideways on the tops of omnibuses with parcels and umbrellas" (Virginia Woolf, Mrs. Dalloway [New York: Harcourt, Inc., 1925, 1981], pp. 4, 17).

${ }^{16}$ It is not clear whether Howells ever read Amy Levy's "Ballade of an Omnibus" (1889). 
whose only connection is that they are all trying to stay dry. This oxymoronic superlative is a correlate to the portrayal of the crowd as the biggest in the universe, and is the direct result of the author's feeling. He grasps the capital's ontology through a synthesis of description with response, realizing this idea through an image of London's factory fumes: "the smoke formed a solution in which all associations were held" (p. 110). Although the narrator presents the concept of smoke-as-memorybank only half-seriously, partly as a pun on the book's title, this usage also demonstrates his determination to connect internal with external experience. ${ }^{17}$ The polluted clouds are paradigmatic of the text, in that they provide a meeting point for both subjectivity and the facticity of urban life. It is clear from a letter that Howells wrote to Elinor that he perceives these twin aspects as being unified: "We came home on an omnibus top, and I felt London." ${ }^{18}$ As London is felt, so it is.

In another interpretation of presentness, Howells claims to be using "instantaneous apparatus" to record the narrator's mental pictures, representing London life through small fragments of time (London Films, p. 47). In one example, he turns his head and spots a group of women "seen newly lighted at a doorway from a passing carriage. . . Occasionally, also, there was a scarf, lightly escaping, lightly caught" (p. 16). The description has balance and a delicacy of touch; in both photographic and literary terms, it is a vignette. The use of "newly lighted" implies "alighted," but also connotes photographic composition taking place in the street. Howells employs the metaphor of fast exposure with his description of the moving scarf, visible for what he calls a "fleeting moment." One of the women catches the scarf as it blows about in the wind, but it is also "caught" by the narrator. He implies the short exposure with "newly," while "Occasionally" suggests the transient nature of the sequence. The two groups soon drift apart, but this is not a

\footnotetext{
${ }^{17}$ For a discussion of the title as referring to fog, see George Arms, "Howells' English Travel Books: Problems in Technique," PMLA, 82 (1967), 113-14.

${ }^{18}$ William Dean Howells, letter to Elinor M. Howells, 12 April 1904, in W. D. Howells, Selected Letters, Volume 5: 1902-I9I I, ed. William C. Fisher with Christoph K. Lohmann (Boston: Twayne Publishers, 1983), p. 93; emphasis in original.
} 
problem for the Kodak-Howells, who is able to record what he needs in a single glance.

Since the Kodak was able to capture its subjects as they walked or ran, the very fact of motion could become a kind of spectacle. Howells exploits this aspect by portraying London's population as being constantly on the move, whether by foot or riding atop a swaying omnibus. This is reminiscent of the earliest "Phantom Ride" films, as well the "Factory Gate" productions of the Lumière Brothers, which kept audiences enthralled with their representations of physical activity. Despite the speed of his exposure, Howells says that London life is sometimes so fast that, like the King's carriage as it speeds past the narrator, it leaves only a "blurred outline" in his mind (London Films, p. 25 ). These shows of movement are concomitant with his use of the word "films," which occurs during a period of transition for photography and the cinema. He states that the term is a reference to the physical material upon which he prints his mental pictures, but this effort to maintain difference is itself "blurred" because it connotes the recently invented cinematograph and mutoscope. According to the Oxford English Dictionary, the first occurrence of "film" to refer to George Eastman's flexible photographic rolls was Walter Woodbury's The Encyclopedia of Photography in 1892. It was straightforward for Cecil Hepworth to adopt the noun in 1897 for the rolls upon which cinematographic productions were printed, and then, two years later, for it to appear as a verb. The first reference to "film" as denoting moving images is from 1905 , the year that Harper and Brothers published London Films. ${ }^{19}$ Between 1892 and 1905 , as the word expanded to encompass photography, cinema, and the act of "filming," it acquired an inescapable liminality. "Film" became a signifier whose alternating referents denied precise communication, posing a serious challenge to any project that linked literature with the latest photographic technology.

In an attempt to avoid this kind of linguistic confusion, Howells twice refers to cinematography as an escape into

\footnotetext{
19 "A firm who took cinematograph films of his operations. . . The films once obtained have been sold and even exhibited at country fairs" (The Western Gazette, 21 January 1905, 3/2; cited in Oxford English Dictionary).
} 
nostalgia. First, when discussing Hampton Court, he writes: "we see Catherine Howard, as in some hideous kinetoscope, escaping from her prison-chamber and running through the gallery to implore the mercy of Henry at mass in the chapel and, as if a phonograph were reporting them, we hear the wretched woman's screams when she is pursued and seized and carried back" (London Films, pp. 129-30). In this (possibly unintentional) allusion to William Dickson's experimental work synchronizing moving pictures with sound, Howells does not perceive the kinetoscope-phonograph as being equivalent to his own perceptions, but rather as a tool. ${ }^{20}$ His appropriation of an apocryphal scene from English history, and his use of extended melodramatic syntax toward the end of the sentence, contrasts the cinematic "film" with its photographic namesake, associating the cinema with fantasy, and photography, by implication, with realism. The second example takes place as the narrator drives past a group of English villagers: "our lightning progress suffered us to behold [them] in a sort of cinematographic shimmer" (London Films, p. 141). Once again, it is motion that conjures up the cinema, as if the people were a series of still images, rolling before the eye at such a speed as to produce the illusion of movement. The term "shimmer" suggests that this medium offers its viewers a splendid but superficial and inconclusive product, presumably in contrast to London Films itself. Yet the word also reminds readers of the carriage that the author described earlier, using the instantaneous Kodak metaphor, as leaving a "blurred outline." Howells is protesting too much at this point, and is showing his uncertainty toward a medium that has technological and etymological roots that overlap those of photography. The effort to isolate these technologies inadvertently forces them together, so that the photographic figuration "Film" is always accompanied by cinematic undertones.

${ }^{20}$ Howells continued to understand moving pictures in terms of use-value. In a 1912 Harper's Magazine article he defended cinema against accusations of moral corruption by noting its potential as an educational tool. In this remarkable article, he anticipates educational television aimed at children and the "documentary" form more generally. See William Dean Howells, "Editor's Easy Chair," Harper's Magazine, 125 (1912), 634-37. To view William Dickson's sound experiment, see "Dickson Experimental Sound Film" (1894-1895), in Edison: The Invention of the Movies [videorecording] (USA: Kino on Video: MoMA, 2005). 
Howells's concern with pictures-of-motion is also a reminder of London Films' reliance on his ability to travel, both physically and intellectually, between England and the United States. Emphasizing a psychological liminality, he establishes a transatlantic corridor down which he can send each new experience. For example, the "woman's hat" sequence quoted above occurs in a chapter entitled "Civic and Social Comparisons, Mostly Odious." In this section Howells details English fashions at length, repeatedly using New York as a point of reference. Many of his descriptions are voyages from one country to another and back again, although this relationality is not only across but also within borders. It is a form of realism in which external things infuse with contrast, a representational mode that inevitably binds itself to memory. He describes London as existing simultaneously in the mind with the mental "films" of previous locations. For example, when the narrator visits St. Paul's Cathedral, the building itself seems to disappear, and is "dwarfed" by his recollection of the recently visited Minster at York (London Films, pp. 77-78). This comparison suggests that contact with physical objects is mediated through the observer's mental lens and that, in empirical terms, the memory of something is actual, because it is an event that occurs, or reoccurs, in the present moment. Howells's description of the buildings stands in stark contrast to that of Nathaniel Hawthorne, who in November 1857 had struggled to visualize both structures simultaneously because he had lacked an experiential theory that would allow him to do so. ${ }^{21}$

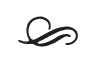

It is a site of critical contention as to whether Howells's output generally displays positivistic features. As critics such as Donald Pizer have noted, much of Howells's work

\footnotetext{
${ }^{21}$ In a November 1857 notebook entry Hawthorne writes: "I wish it were possible to pass directly from St Paul's into York Minster, or from the latter into the former; that is, if one's mind could manage to stagger under both, in the same day. There is no other way of judging their comparative effect" (Nathaniel Hawthorne, "Passages from the English Note-books of Nathaniel Hawthorne," in Our Old Home and English Note-books, 2 vols. [Boston and New York: Houghton, Mifflin and Co., 1898 , entry originally written in 1857 ], II, 573 .
} 
demonstrates a belief in a scientifically penetrable universe, an assumed fixity of subject and object, and an emphasis on teleological systems such as evolution. ${ }^{22}$ These elements manifest themselves in a gradual accumulation of textual detail, a maintenance of an antisentimental tone, a separation of external from internal life, and, at least in his fiction, the absence of the first-person voice. Emily Fourmy Cutrer makes it clear, however, that Howells also attends to the vicissitudes of empirical existence, testing preexisting models of representation against the pragmatic work of everyday living. ${ }^{23}$ In 1886 Howells declared that the only books that he wished to read were those that "represent and body forth human experience." ${ }^{24}$ Authors, according to this view, should write about what they personally know, rather than projecting speculative worlds that could turn out to be untrue. He elsewhere insists that society is entering upon a "communistic era" in the realm of taste, during which authors will be able to draw upon a universal standard of aesthetic value: nature itself. ${ }^{25}$ On the one hand, then, his work maintains a "scientific" detachment to a real and reliable world, but on the other hand, it commits itself to recording the experience of a certain class of nineteenth-century men, and occasionally women-a balancing act that was, in Miles Orvell's words, akin to "a tightrope walker holding a china tea cup."26

Although Howells's novels of the 188 os and 1890 share pragmatic concerns, nowhere do they merge subjective and objective knowledge in the moment of experience, sense data plus conjunctive relations, as later occurs in London Films. Many of Howells's earlier writings remain in a state of tension between faith in objectivity and a concentration upon a narrow definition of "human experience" as the best way of interpreting data.

${ }^{22}$ See Pizer, Realism and Naturalism in Nineteenth-Century American Literature, revised ed. (Carbondale and Edwardsville: Southern Illinois Univ. Press, 1984), pp. 1-4, $70-71$.

${ }^{23}$ Cutrer, "A Pragmatic Mode of Seeing: James, Howells, and the Politics of Vision," in American Iconology: New Approaches to Nineteenth-Century Art and Literature, ed. David C. Miller (New Haven: Yale Univ. Press, 1993), pp. 259-75.

${ }^{24}$ William Dean Howells, "Editor's Study" (May 1886), in Editor's Study, p. 197.

${ }^{25}$ See Howells, Criticism and Fiction, p. 3 oo.

${ }^{26}$ Orvell, The Real Thing: Imitation and Authenticity in American Culture, I880-1940 (Chapel Hill: Univ. of North Carolina Press, 1989), p. 108. 
The tug-of-war between these structures of thought, which is by no means limited to Howells, intensifies around the turn of the century. This was a period of instability, during which the ideology of the liberal establishment had been threatened by a militant, increasingly non-English-speaking proletariat, violent vigilante groups mostly operating in the South, and a political elite who saw the country's future role as that of a European-style imperial power. Such a context was fertile ground for theories that promised to resolve the disconnection between universality and the worldview of the bourgeoisie.

For William James that theory was radical empiricism. James argues that positivism, the dominant nineteenth-century paradigm, is overly dualistic in its presupposition that subject and object are irreducible. In Essays in Radical Empiricism (1912), James insists that Hippolyte Taine, who brought Auguste Comte's positivist thought to the study of literature, conceives human sensation as being a mere facsimile of external life. For James inner and outer existences are inseparable, or, as he puts it: "subject and object fuse together." ${ }^{27}$ Just as a point on a graph is the meeting place for two separate axes, so experience consists in the relation between externality and subjectivity. In a passage that is reminiscent of the descriptions of the English cathedrals in London Films, James writes that his "idea" of Harvard University's Memorial Hall is not empirically different from its presence: “'Memorial Hall' is 'there' in my idea as much as when I stand before it. I proceed to act on its account in either case. Only in the later experience that supersedes the present one is this naïf immediacy retrospectively split into two parts, a 'consciousness' and its 'content,' and the content corrected or confirmed." 28 Consciousness, according to James, does not exist in and of itself, or apart from the content of things. This means that perception is not a copy of life, but is itself a type of reality. Such claims blur the Cartesian binary of theoretic

\footnotetext{
${ }^{27}$ William James, “'La Notion de Conscience': Translation,” trans. Salvatore Saladino, in William James, Essays in Radical Empiricism (Cambridge, Mass.: Harvard Univ. Press, 1976), p. 263 ("Le sujet et l'objet se confondent") "La Notion de Conscience" was originally presented in 1905 .

${ }^{28}$ William James, "A World of Pure Experience" (1904), in Essays in Radical Empiricism, p. 37 .
} 
cognition versus material extension, to which both Taine and Comte assent. In turn, it alters the traditional relationship between the observer and that which is observed. For Howells it also has useful similarities to the physically embodied way in which consumers used the new Kodaks.

Despite the fact that Howells and James share a strong intellectual connection, there is no criticism linking Essays in Radical Empiricism to London Films. This is presumably because, while James wrote his book as a series of lectures and articles between 1904 and 1906, it did not emerge as a complete work until after his death, a full seven years after the publication of London Films. Whether Howells attended any of James's talks or read any of his original articles is unclear, but he was certainly aware of the direction in which his friend's thought was tending. ${ }^{29}$ In 1913 Howells wrote to William James's son, Henry James III, in praise of the "wonderful commonsense psychology" of Essays in Radical Empiricism. ${ }^{30}$ As is clear from contemporary reviews, many in the academy considered James's integration of the concepts of subject and object to be dangerously counterintuitive. ${ }^{31}$ It was Howells's previous familiarity with James's work

${ }^{29}$ This is because he had already read James's critique of positivism and his embryonic outline of radical empiricism in The Varieties of Religious Experience (1902). In 1902 Howells promised James that he would soon read Varieties, and a 1917 letter to James's wife, Alice Howe James, confirms that he followed through on this promise. See William James, letter to William Dean Howells, 28 September 1902; and Howells, letter to Alice Howe James, 26 February 1917, Houghton Library collection, bMS Am I 784 (225) and bMS Am I092.9 (4313). By permission of the Houghton Library, Harvard University. See also Howells, letter to William James, 7 October 1902, in Selected Letters, Volume 5, p. 35 .

${ }^{30}$ William Dean Howells, letter to Henry James III, 15 August 1913, in W. D. Howells, Selected Letters, Volume 6: I9I 2-1920, ed. William M. Gibson and Christoph K. Lohmann (Boston: Twayne Publishers, 1983), p. 4o. The editors' footnote to this letter states that Howells's reference to "your father's book" is probably intended to indicate William James's Some Problems of Philosophy: A Beginning of an Introduction to Philosophy (1911), giving the justification that Henry James III had provided a "Prefatory Note" for this book. Yet the philosopher's son also involved himself in the publication of Essays in Radical Empiricism by reserving the copyright in his name. Howells's reference could be to either book, or even to another. Given that Howells wrote the letter in 1913 , only a year after the publication of Essays in Radical Empiricism and two years after that of Some Problems of Philosophy, he is probably referring to Radical Empiricism.

${ }^{31}$ For example, see John E. Russell, "Some Difficulties with the Epistemology of Pragmatism and Radical Empiricism," Philosophical Review, 15 (19o6), 406-13. For more information regarding the reception of Essays in Radical Empiricism, see Eugene I. 
that enabled him to make his dissenting statement. That he referred to James's conclusions as "commonsense," a term similar to those in which he discussed his own practice, suggests that Howells felt that they had a utility for interpreting the everyday in an original but accessible manner. Although his statement is in part a polite tribute to a man who had passed away three years earlier, it also reflects his admiration of a theory that had provided a springboard for an epistemological reevaluation.

Recent criticism has usefully discussed Howells in relation to pragmatism, particularly to James's foundational text The Principles of Psychology (1890). ${ }^{32}$ Much of this work has implied that radical empiricism and pragmatism are in some way interchangeable, a view that James himself explicitly rejected, but one that took hold because of Ralph Barton Perry's conflation of these terms in his 1912 preface to Essays in Radical Empiricism. ${ }^{33}$ Against this view, I claim that pragmatism is a method by which James arrives at radical empiricism, but that the two concepts are not interchangeable because radical empiricism concerns itself with merging subject and object in a way that is not essential to pragmatism. ${ }^{34}$ To illustrate the malleability of pragmatism, James was fond of using the metaphor of a hotel corridor leading off to different rooms, representing the way in which pragmatism might interconnect with various philosophical traditions. The only published exploration of radical empiricism as such in relation to Howells is Sämi Ludwig's

Taylor and Robert H. Wozniak, "Pure Experience: The Response to William James: An Introduction," in Pure Experience: The Response to William James, ed. Eugene Taylor and Robert Wozniak (Bristol: Thoemmes Press, 1996), pp. ix-xxxii.

${ }^{32}$ See Sarah B. Daugherty, "A Hazard of New Fortunes: Howells and the Trial of Pragmatism," American Literary Realism, 36 (2004), 166-79.

${ }^{33}$ For example, Paul R. Petrie claims that "James defines pragmatism as the practice of 'radical empiricism"" (Petrie, "Racial Duties: Toward a Pragmatist Ethic of Race in W. D. Howells's An Imperative Duty," Nineteenth-Century Literature, 63 [2008], 231). See also Ralph Barton Perry, "Editor's Preface," in William James, Essays in Radical Empiricism (New York and London: Longmans, Green, and Co., 1912), pp. iii-xiii.

${ }^{34}$ This is not to suggest that radical empiricism is not pragmatic, but simply that it is not pragmatism. As James puts it: "there is no logical connexion between pragmatism, as I understand it, and a doctrine which I have recently set forth as "radical empiricism.' The latter stands on its own feet" (William James, "Preface" to his Pragmatism: A New Name for Some Old Ways of Thinking [London: Longmans, Green, and Co., 1907], p. ix). 
excellent Pragmatist Realism (2002). ${ }^{35}$ Somewhat surprisingly, however, Ludwig's analysis of Howells as critiquing perceptualism, the idea that reality can be accurately represented in pictures, omits the medium of photography. Ludwig implies that, from the cradle to the grave, Howells maintained a single view of perceptualism, and that the invention of new photographic methodologies had no influence whatsoever upon his opinion of pictures. In doing so, Ludwig does not take into account the length of Howells's career or the incredible changes that took place in the fields of photography, cinema, and painting during that time. If Howells were wholly and universally skeptical of pictorial representations, then he would not have called his mode of realism "photographic," or set himself up as the radically empiricist Kodak of London Films.

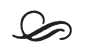

Howells's synthesis of radical empiricism with literary realism is bold but problematic, particularly in relation to his efforts at social exploration. When critics have given it any attention at all, they have generally descried London Films for its apparent blindness to the reality of poverty: Carol Shloss, for example, calls it "audaciously uninformed." ${ }^{36}$ It is certainly the case that, in contrast to sociologists such as Joseph Rowntree, Howells does not portray an accurate spectrum of the English poor. What he provides instead is contained in the title of the main chapter dealing with his visits around London's poorer areas: "Glimpses of the Lowly and the Lowlier" (London Films, p. 88; emphasis added). His fragmented approach is the result of a technologically mediated crisis of perception. Howells's decision to remove his vision from what was a previously fixed framework of signification leads him to doubt the totality and, at times, even the essence of what the narrator witnesses. For example, he says that he did not see much alcoholism during

\footnotetext{
${ }^{35}$ See Ludwig, Pragmatist Realism: The Cognitive Paradigm in American Realist Texts (Madison: Univ. of Wisconsin Press, 2002).

${ }^{36}$ Shloss, In Visible Light: Photography and the American Writer: $1840-1940$ (New York: Oxford Univ. Press, 1987), p. 87 .
} 
the trip, but then adds: "Of course, the statistics will probably be against me . . . and I offer my observations as possibly inexact. One can only be sure of one's own experience (even if one can be sure of that)" (p. 99). This half-apologetic, parenthetical admission is also a statement of belief; or rather, it states the fragility of belief itself. The text cannot give precise reports because it takes place within what its author calls "an age of doubt" (p. 172), during which his epistemic ambitions are far lower than in previous times.

Howells-as-narrator traces a history of this loss of confidence in the power of literary examination through a chronology of his visits to the English capital. He states that he had thought himself, after only a few days' stay in 1861 and again in 1865 , "a profound observer" of London. This feeling had diminished by his next stop in 1882 , while by 1904 he realized that he could only ever reach a "diffident inconclusion" about the city (London Films, p. 2). The implication is that the more data he possesses, the harder it becomes to write fixed analyses. These are reluctant admissions, however, and he regrets being unable to apply "Roentgen rays ... to certain aspects of the London world" (p. 2). Howells's inability to use scientific methods of seeing beneath surfaces also has a biographical context. His brother, Henry, suffered from learning difficulties, which his family had hoped to "cure" by the use of x-rays. Howells's correspondence indicates that the operation was his suggestion, and so it is unsurprising that he suffered great disappointment when it was unsuccessful. ${ }^{37}$ He alludes to this same technique in London Films only a year later, when the failure must have been fresh in his mind.

Leading on from this loss of faith in the idea of absolute knowledge, the writer's inconsistencies bring him and the Kodak together. In language that is suggestive of his review of Walworth, Howells concedes that his "faulty impressions" may require the reader "to sharpen the blurred details, to soften the harsh lights" of the images that he presents (London Films,

\footnotetext{
${ }^{37}$ See William Dean Howells, letter to Joseph Howells, 14 July 19o3, and William Dean Howells, letters to Aurelia Howells, 6 September and 27 September 1903, Houghton Library Collection, $b M S A m$ I $784 . I$ (72) and $b M S A m$ I $784 . I$ (67). By permission of the Houghton Library, Harvard University.
} 
p. 1). The inference is that his descriptions, referred to as "involuntary glimpses" (p. 169), are like snapshots not only in their speed but also because he took them without professional composure, and that they are, therefore, flawed. Since modernity is too complex for "faulty impressions" to capture with exact verisimilitude, his empirical imperfections reveal themselves through technical deficiencies. For example, he comments that the "mental photograph," like its real-world equivalent, cannot capture color. Immediately afterward, he notes the conversation of a group of friends but admits that his Kodak is incapable of recording sound (pp. 17-18). Such insecurities are the result of thinking self-consciously and concurrently about the process of depiction. The text's subtle and reflexive handling of information highlights the limits of knowledge, pushing at the boundaries of representation to the point where the previously assumed connection between literature and the world comes close to collapse. Howells's intention with London Films is to reinvigorate literary realism; yet, in making this attempt, he fears that he is anticipating its demise. The narrator asks: "So improbable, so sensational is life even to the most bigoted realist! But if it is so, why go outside of it?" (p. 81). It is unclear whether this is truly a rhetorical question, because it suggests both Howells's intention to stay within realism as well as a concern that this may not be possible. It also implies that a widespread abandonment of the realist project may eventually emerge from an "improbable" reality rather than from the familiar, and more easily dismissed, realm of romance.

While noting that he saw little poverty during his 1904 visit to London, the narrator states that images of the intense hardship witnessed during previous trips haunt his walks around the city (London Films, p. 95). Jamesian memory, appearing here as a lived experience, feeds back on itself in order to comment on the inadequacy of present accounts. This nostalgia for a time when it was possible to witness poverty encapsulates a political and moral dilemma: if you can no longer be sure of what you see, then how can you describe the injustices and sufferings of humanity? London Films is unable to answer this question because of its emphasis on the limited but inescapable nature of interiority. In this sense, both Howells and James fail to achieve synthesis. As Richard Rorty notes, James does not remove the 
subject-object binary, but merely flips the dominant term. By claiming that a world of "pure experience" is more real than science, James retains a fundamentally Cartesian dualism. ${ }^{38}$ Through its shift to a Jamesian mode of phenomenological response, London Films exchanges one set of metaphysical assumptions for another. Yet it also retreats from the furthest implications of James's work, hovering between an adherence to two opposing conceptions of the relationship between artistic creation and the world.

Howells ultimately abandoned his project to create a literary version of radical empiricism, readopting a positivistic method of description with his next publication, Certain Delightful English Towns (1906). In contradistinction to London Films, in this work he warns readers not to take an omnibus to Canterbury Cathedral because it would be too crowded, recommending instead that they take a one-person fly. Traveling in this privatized vehicle, he reestablishes a discourse of distance and a perfect vision that is able to "absorb every particular" of the journey. ${ }^{39}$ In the 1909 preface to the 1911 "Library Edition," which collected these two "English" volumes together, Howells reflected that he had selected the title London Films "in a moment of reckless, of almost cynical, indifference." 40 Given that this designation encompasses the book's central conceit, the implication is that not only the act of naming, but also the act of writing London Films was irresponsible, perhaps even dangerous. His concern is that he may not have expanded realism, but instead highlighted the possibility of working in an altogether different way. In this context, London Films not only represents a neglected example of realism's intellectual crisis, but it also places its author firmly within the sphere of early-twentiethcentury literary experimentation.

In an "Editor's Study" article of February 189o, Howells wrote that realism was "the photographic school in fiction," a

\footnotetext{
${ }^{38}$ Richard Rorty, "Some Inconsistencies in James's Varieties," in William James and a Science of Religions: Reexperiencing "The Varieties of Religious Experience," ed. Wayne Proudfoot (New York: Columbia Univ. Press, 2004), pp. 86-97.

${ }^{39}$ William Dean Howells, Certain Delightful English Towns, in "London Films" and "Certain Delightful English Towns," p. 4o9.

${ }^{40}$ William Dean Howells, "Bibliographical," in "London Films" and "Certain Delightful English Towns," p. xi. The preface is dated July 1909.
} 
commonplace assertion conflating the various photographies with which this type of literature was comparable. ${ }^{41}$ Yet his later practice links itself to the qualities, possibilities, and limitations of specific technologies. Altering the definition slightly, I claim that London Films represents a "Kodak school in fiction": writing that is committed to recording external reality accurately, through a combination of speed, visuality, physical being-inthe-world, and unpredictable internal impressions. Further research might examine the narratives of Howells's contemporaries in relation to this Kodak figure. Such a move would assist in further investigations concerning how realists and naturalists approached their work, providing a term to intersect the ambiguously defined forms in which they wrote. This discussion would not be undertaken in order to create a new ontology, but to provide a contextual and conceptual filter through which to make potentially productive connections.

\section{University of Leeds}

\section{ABSTRACT}

Owen Clayton, "London Eyes: William Dean Howells and the Shift to Instant Photography" (pp. 374-394)

Toward the end of the nineteenth century, one of William Dean Howells's many avid readers, finally meeting him in the flesh, expressed surprise that the famed writer was not dead. Although he had not actually departed from the world, it was true that by this time the venerable "Dean" was at a low ebb. While younger authors were taking the novel in directions about which he was, at the least, ambivalent, Howells was aware that his own best work was behind him. Yet, throughout his career, he maintained a desire to test different literary approaches. In England in 1904, Howells tested a conceit that would allow him to keep pace with the literary movements of the day. This consisted of an extended photographic metaphor: an association of himself with the Kodak camera. He used this figuration to move beyond the philosophical foundations of his previous work. Criticism has largely overlooked this endeavor, which Howells buried away in the somewhat obscure travelogue London Films (1905). This essay shows how London Films used its photographic metaphor to question positivistic observational assumptions, the way in which this was a response to William James's Essays in Radical Empiricism (1912), and, finally, why Howells ultimately went back on his attempt to create a Kodak school in fiction.

Keywords: William Dean Howells; photography; representations of London; William James; literary Realism

\footnotetext{
${ }^{41}$ Howells, "Editor's Study" (February 189o), in Editor's Study, p. 239.
} 